\title{
Differential scanning calorimetry of whole Escherichia coli treated with the antimicrobial peptide MSI-78 indicate a multi-hit mechanism with ribosomes as a novel target
}

Alexander M Brannan, William A Whelan, Emma Cole, Valerie Booth

Differential Scanning Calorimetry (DSC) of intact Escherichia coli (E. coli) was used to identify non-lipidic targets of the antimicrobial peptide (AMP) MSI-78. The DSC thermograms revealed that, in addition to its known lytic properties, MSI-78 also has a striking effect on ribosomes. MSI-78's effect on DSC scans of bacteria was similar to that of kanamycin, an antibiotic drug known to target the $30 \mathrm{~S}$ small ribosomal subunit. An in vitro transcription/translation assay helped confirm MSI-78's targeting of ribosomes. The scrambled version of MSI-78 also affected the ribosome peak of the DSC scans, but required greater amounts of peptide to cause a similar effect to the unscrambled peptide. Furthermore, the effect of the scrambled peptide was not specific to the ribosomes; other regions of the DSC thermogram were also affected. These results suggest that MSI-78's effects on E. coli are at least somewhat dependent on its particular structural features, rather than a sole function of its overall charge and hydrophobicity. When considered along with earlier work detailing MSI-78's membrane lytic properties, it appears that MSI78 operates via a multi-hit mechanism with multiple targets. 
1 Differential scanning calorimetry of whole Escherichia coli

2 treated with the antimicrobial peptide MSI-78 indicate a multi-

3 hit mechanism with ribosomes as a novel target.

4 Alex Brannan ${ }^{1}$, Will Whelan ${ }^{1}$, Emma Cole ${ }^{1}$, Valerie Booth ${ }^{1,2}$

5

6 1Department of Biochemistry, ${ }^{2}$ Department of Physics and Physical Oceanography

7 Memorial University of Newfoundland

8

9 


\section{Abstract}

11 Differential Scanning Calorimetry (DSC) of intact Escherichia coli (E. coli) was used to 12 identify non-lipidic targets of the antimicrobial peptide (AMP) MSI-78. The DSC

13 thermograms revealed that, in addition to its known lytic properties, MSI-78 also has a 14 striking effect on ribosomes. MSI-78's effect on DSC scans of bacteria was similar to 15 that of kanamycin, an antibiotic drug known to target the $30 \mathrm{~S}$ small ribosomal subunit. 16 An in vitro transcription/translation assay helped confirm MSI-78's targeting of 17 ribosomes. The scrambled version of MSI-78 also affected the ribosome peak of the 18 DSC scans, but required greater amounts of peptide to cause a similar effect to the unscrambled peptide. Furthermore, the effect of the scrambled peptide was not specific

20 to the ribosomes; other regions of the DSC thermogram were also affected. These 21 results suggest that MSI-78's effects on $E$. coli are at least somewhat dependent on its 22 particular structural features, rather than a sole function of its overall charge and 23 hydrophobicity. When considered along with earlier work detailing MSI-78's membrane 24 Iytic properties, it appears that MSI-78 operates via a multi-hit mechanism with multiple 25 targets. 


\section{Introduction}

AMPs are a crucial component of the innate immune system of many organisms and can protect against a variety of invading pathogens including bacteria, viruses, and microbial eukaryotes (Shai, 1999; Zasloff, 2002; Jenssen et al., 2006; Nguyen et al., 2011; Wimley and Hristova, 2011; Bechinger and Salnikov, 2012). AMPs have been isolated from a plethora of organisms, including plants, humans, frogs, and bacterial species. They are generally short, typically ranging from 12 to 50 amino acids in length, cationic, due to an abundance of basic residues (lysine, arginine, histidine), and amphipathic, with some AMPs displaying a hydrophobicity of $>50 \%$. These characteristics are important in driving the interactions of AMPs with the membrane of target pathogens, which can result in the direct killing of the pathogen via membrane disruption, and/or provide a means for the AMP to access intracellular targets.

Much hope has been expressed for the potential of novel AMP-based therapeutics to help address the growing problem of antibiotic resistance to conventional small antibiotics (Rossi et al., 2008; Spellberg et al., 2008; Boucher et al., 2009; Yeung et al., 2011). However, successfully developing AMP-based drugs, in particular for internal use, has proved very challenging (Matsuzaki, 2009; Wimley and Hristova, 2011; Pasupuleti et al., 2012). One major barrier to the optimization of AMPs for therapeutic use rests with the simplified model membrane systems in which detailed mechanistic studies and AMP sequence optimization are generally performed. By focusing solely on the lipids, studies that are limited to model membrane systems fail to capture the myriad of potentially important interactions that AMPs may have with their target microbes.

An example of the gap that exists between mechanistic studies in model membranes and the conditions under which AMPs actually carry out their function is the observation that AMPs cause leakage in model membranes at protein:lipid $(P: L)$ ratios $\sim 10,000$ times lower than the $P: L$ ratio needed to see bacterial growth inhibition (Wimley, 2010). On the one hand, solid state NMR, vesicle leakage and other biophysical experiments aimed at understanding the structural mechanisms of AMPinduced bilayer disruptions employ model membranes and overall AMP:lipid molar 
58 ratios of $\sim 1: 200$ (Wimley, 2010). On the other hand, the minimal inhibitory

59 concentration (MIC) assays used to define the concentration of AMP needed to prevent bacterial growth are typically performed with overall molar ratios of 1000 AMP:1 lipid a difference in AMP:lipid ratio of $\sim 5 \times 10^{6}$ compared to the biophysical studies. Furthermore, the hemolytic assays that are frequently used to indicate host cell toxicity are done at orders of magnitude higher cell densities than MIC assays (Matsuzaki, 2009; Wimley, 2010). This results in very different $P: L$ ratios (e.g 1:15 for our hemolytic assay at $24.35 \mathrm{ug} / \mathrm{mL} \mathrm{MSI}-78$ ) of 3 to 4 orders of magnitude less AMP per lipid as compared to the MIC assays. Beyond these very disparate experimental protocols, it should also not be forgotten that in vivo, there will be a competition between AMP-pathogen binding and AMP-host cell binding that may alter the effective selectivity of an AMP for the pathogen (Bagheri et al., 2015). Attempts to make sense of these disparate experimental conditions have been made by working out a more "local" (to the membrane) AMP concentration. For example, Melo, Ferre and Castanho (Melo et al., 2009) took the approach of assuming that the AMP would bind only the lipid component of the bacteria and used known partition constants to suggest that AMP:lipid ratios of 1:16 at the membrane could be achieved for the pathogen densities expected for in vivo conditions. Alternatively, Wimley (Wimley, 2010), estimated how much AMP would actually bind to the bacteria in a typical MIC experiment and came up with 100:1 for the bound AMP:lipid ratio. From this he concluded that much of the AMP must bind to nonlipidic cell components to account for the discrepancy between the amounts of peptide needed to see disruption in model membranes versus bacteria. Even the relative leakage induced in model lipid membranes by different AMPs does not always correlate with their relative ability to prevent bacterial growth (Friedrich et al., 2000; He et al., 2014).

Thus, while AMP-lipid interactions are key in understanding AMP mechanism, it is vital to look beyond model membranes and examine AMPs' potentially functional interactions with other components of the target cell. While the vast majority of studies of AMP mechanism have focused on lipids, there are indeed AMPs for which non-lipidic intracellular targets are known (Brogden, 2005; Marcos and Gandia, 2009), although AMP-membrane interactions can still be important for allowing AMPs to access the 
89 interior of the cell. Known non-lytic mechanisms for AMPs include targeting nucleic 90 acids (Park et al., 1998), chaperones (Kragol et al., 2001), cell wall synthesis (Brotz et 91 al., 1998), protein synthesis (Patrzykat et al., 2002), and enzymatic activity (Andreu and 92 Rivas, 1998), as well as the G-quadruplex in mammalian cancer cells (Jana et al., 93 2013). does not reach the bilayer and may remain in association with non-lipidic components of

114 the cell envelope and 2) even at relatively low levels of MSI-78, there is a large degree 115 of membrane disruption, suggesting that the peptide may be able to reach the inside of

116 the cells and interact with an intracellular component. Thus, to further probe the

117 interaction of MSI-78 with intact bacteria, we turned to DSC, a method that, in principle,

118 can be used to simultaneously reveal the effect of the peptide on lipid and non-lipidic

119 cell envelope components, as well as intracellular components, of intact $E$. coli. 
Whole cell differential scanning calorimetry (DSC) has been used to characterize

121 the thermal stability of cell components in bacterial cells (Miles et al., 1986; Mackey et

122 al., 1988; Lepock et al., 1990b; Anderson et al., 1991; Anderson et al., 1991; Mackey et

123 al., 1991; Mackey et al., 1993; Teixeira et al., 1997; Mohácsi-Farkas et al., 1999; Bayles

124 et al., 2000; Lee and Kaletunc, 2002a; Lee and Kaletunc, 2002b; Alpas et al., 2003;

125 Kaletunc et al., 2004; Lepock, 2005; Nguyen et al., 2006; Tunick et al., 2006; Abuladze

126 et al., 2009; Lee and Kaletunç, 2010), archaeal cells (Milek et al., 2007), endospores

127 (Belliveau et al., 1992), and eukaryotic cells (Lepock et al., 1990a; Obuchi et al., 2000).

128 DSC has also been used to probe the mechanisms of numerous AMPs in model

129 membrane systems, including the cathelicidins (Andrushchenko et al., 2007), LL-37

130 (Sevcsik et al., 2007), $\beta-17$ (Epand et al., 2003), and MSI-78 (Hallock et al., 2003;

131 Ramamoorthy et al., 2006). The aim of our study was to use DSC to reveal the

132 interactions of MSI-78 with components of whole cells, in particular with the non-lipidic

133 cell envelope and intracellular cell components.

Materials and Methods

136 Peptide and bacteria preparation. MSI-78 (Maloy and Kari, 1995) and a scrambled 137 version of MSI-78 were chemically synthesized, purified by HPLC, and desalted, as in

138 (Pius et al., 2012). Stocks of $60 \mu \mathrm{L}$ E. coli JM109 (1:1-culture/glycerol) were stored at -

$13980^{\circ} \mathrm{C}$ until use. $50 \mu \mathrm{L}$ of culture was added to $10 \mathrm{~mL}$ of Luria-Bertani (LB) broth in $15 \mathrm{~mL}$ 140 conical tubes and placed overnight in an incubator at $37.0^{\circ} \mathrm{C}$ rotating at $160 \mathrm{rpm} .200$

$141 \mu \mathrm{L}$ of this overnight culture was then used to inoculate $20 \mathrm{~mL}$ sterile LB broth in a 100

$142 \mathrm{ml}$ Erlenmeyer. This was grown, under the same conditions described above, until the

143 bacterial culture reached mid-log phase as indicated by an optical density of

144 approximately 0.65 when measured at a wavelength of $600 \mathrm{~nm}$. Ten $\mathrm{mL}$ of this mid log 145 culture was transferred to a $50 \mathrm{~mL}$ centrifuge tube and centrifuged at $4100 \mathrm{~g}$, at $4^{\circ} \mathrm{C}$, for

14610 minutes in a Thermo Sorvall RC6+ Centrifuge, using an f21s (6x50) rotor (Thermo

147 Fisher Scientific Inc., Waltham, MA). The supernatant was discarded and $2 \mathrm{~mL}$ of M9

148 minimal media ( $K$ and $R$, 2002) was added and the cells were resuspended by gentle 149 vortexing. 
150 Peptide and antibiotic treatment. Peptides were added as a weight percent of the dry 151 weight of bacterial cells present. Bacterial cell dry weight was calculated in accordance 152 with a previously established standard curve (Pius et al., 2012) relating the OD600 to

153 the dry weight of cells present, and used to calculate the amount of peptide required for 154 a particular treatment. An appropriate amount of a $1 \mathrm{mg} / \mathrm{ml}$ stock of AMP, or antibiotic, 155 either kanamycin or streptomycin (Sigma-Aldrich CO, St. Louis, MO) stock solution was 156 added after resuspension of JM109 cells in M9, followed by gentle inversion (at room 157 temperature) to mix the JM109 cells and peptide.

158 Differential Scanning Calorimetry (DSC). Immediately after peptide or antibiotic

159 treatment, the samples and reference solutions were degassed on ice for 5-10 minutes.

160 M9 minimal media was used for the reference cell. After degassing, the sample and 161 reference were loaded into the cells of a Nano DSC (TA Instruments, New Castle, DE), 162 taking care not to introduce any air bubbles. The DSC and samples were equilibrated 163 during a brief DSC scan from $25^{\circ} \mathrm{C}$ to $5^{\circ} \mathrm{C}$. Scans were performed immediately 164 afterward, with a temperature increase from $5^{\circ} \mathrm{C}$ to $125^{\circ} \mathrm{C}$ at a rate of $0.5^{\circ} \mathrm{C} / \mathrm{min}$, under 165 a pressure of $3 \mathrm{~atm}$. Samples were cooled back to $5^{\circ} \mathrm{C}$ and a rescan performed. After 166 completion the DSC cell was washed with $1 \mathrm{~L}$ of distilled water, $1 \mathrm{~L}$ of $2 \%$ Contrad, and 167 then $1 \mathrm{~L}$ of distilled water.

Raw DSC data was plotted using the program DataGraph (Visual Data Tools Inc.). The water-water baselines for our DSC instrument are linear and the sample rescans are also linear with the exception of a few small peaks. Thus, we opted to subtract linear baselines only from the data, rather than employing a more complicated, and potentially artifact-prone baseline subtraction scheme. The baselines we used were linear fits to the high and low temperature extremes of the plotted data and were subtracted from the raw scans. That is to say, for each temperature range of interest and displayed in the figures, a separate linear fit to the endpoints was performed and subtracted from the scan. Minimal inhibitory concentration assays. Minimal Inhibitory Concentration (MIC) assays 178 were carried out using JM109 Escherichia coli. The working concentration was $1.6 \times 10^{5}$ $179 \mathrm{cfu} / \mathrm{mL}$ in Mueller Hinton (MH) broth. MSI-78 was dissolved in $20 \mathrm{mM}$ sodium phosphate 
180 buffer, $\mathrm{pH}$ 7, to give a concentration of $1 \mathrm{mg} / \mathrm{mL}$. $100 \mu \mathrm{L}$ of MSI-78 solution was added

181 to wells B2 and C2 of an untreated, sterile 96-well polypropylene plate. Peptide

182 concentrations ranged from $250 \mu \mathrm{g} / \mathrm{mL}$ to $0.49 \mu \mathrm{g} / \mathrm{mL}$. Sodium phosphate buffer

183 controls $(v=100 \mu \mathrm{L})$ were added to wells D2 and E2. $100 \mu \mathrm{L}$ of Solution A (0.04 \% acetic

184 acid + $0.02 \%$ bovine serum albumin) was added to rows B2-B11, C2-C11, D2-D11, and

185 E2-E11. Serial dilutions were carried out by addition of $100 \mu \mathrm{L}$ of previous well to

186 subsequent wells in the lettered row (ie. $100 \mu \mathrm{L}$ of B2 added into B3). $100 \mu \mathrm{L}$ of column

18711 was discarded to keep same working volume. $100 \mu \mathrm{L}$ of diluted JM109 (1/200) was

188 added to all wells. Controls included bacteria and $\mathrm{MH}$ broth alone. The plates were

189 incubated at $37^{\circ} \mathrm{C}$ in a shaking incubator set at 140 RPM for $16 \mathrm{~h}$. The MIC was defined

190 as the lowest concentration of peptide that resulted in no bacterial culture growth as

191 judged by visual inspection of the opacity.

193 Hemolytic Assay. Hemolytic assays were performed in triplicate to test MSI-78 and

194 scrambled MSI-78 activity against eukaryotic (human) cells. Erythrocytes were obtained

195 from blood collected in a $60 \mathrm{~mL}$ conical tube with an EDTA anti-coagulant. This was

196 then transferred to $15 \mathrm{~mL}$ conical tubes, and the level of blood was marked with a

197 permanent marker. The tubes were centrifuged at $3000 \mathrm{rpm}$ at $4^{\circ} \mathrm{C}$ for 15 minutes. The

198 plasma was discarded and erythrocytes were resuspended in $150 \mathrm{mM}$ Tris-HCl buffer to

199 the marked line levels, giving the same concentration of erythrocytes as was present in

200 the previous step. Two more washing steps of centrifugation and cell resuspension

201 were completed. After the final washing, the erythrocytes were resuspended in the

202 appropriate volume of $100 \mathrm{mM}$ sodium phosphate buffer, $\mathrm{pH} 7$. A $1 \mathrm{~mL}$ sample of this

203 resulting solution was added to $9 \mathrm{~mL}$ of $100 \mathrm{mM}$ sodium phosphate buffer for a dilution

204 of $1: 10$. This yielded an erythrocyte concentration of approximately $5 \times 10^{8}$ cells $/ \mathrm{mL}$.

206 Two stock peptide solutions were made: $0.5 \mathrm{mg} / \mathrm{mL}$ MSI-78 and scrambled MSI-78.

207 Solutions were made in $100 \mathrm{mM}$ phosphate buffer and appropriate volumes were added

208 to give the desired concentration in a $1.30 \mathrm{~mL}$ sample volume. Then, $200 \mu \mathrm{L}$ of the

209 diluted erythrocytes was added. The final concentrations of the peptides after these 
210 dilutions were $24.35 \mathrm{mg} / \mathrm{mL}$ and $48.7 \mathrm{mg} / \mathrm{mL}$ for both peptides that were assayed. Two

211 controls were utilized, one exhibiting $100 \%$ hemolysis, and one that exhibits $0 \%$. The

212 positive (100\%) control was made by adding $200 \mu \mathrm{L}$ of diluted erythrocytes to $1.3 \mathrm{~mL}$ of

$2131 \%$ Triton X-100 detergent solution in $100 \mathrm{mM}$ sodium phosphate buffer. The negative

$214(0 \%)$ control was made by adding $200 \mu \mathrm{L}$ of diluted erythrocytes to $1.3 \mathrm{~mL}$ of $100 \mathrm{mM}$

215 sodium phosphate buffer. Solutions were incubated in a water bath for an hour at $37^{\circ} \mathrm{C}$.

216 Samples were then centrifuged at $3000 \mathrm{rpm}, 4^{\circ} \mathrm{C}$ for 15 minutes to pellet any

217 erythrocytes that were not lysed. The supernatants were collected by pipette into

218 cuvettes and measured at $541 \mathrm{~nm}$ on a Genesys $10 \mathrm{~S}$ UV-VIS Thermo Scientific

219 Spectrometer (Thermo Fisher Scientific Inc., Waltham, MA).

220 Percent hemolysis was calculated by using the equation:

221

222

$$
\% \text { Hemolysis }=\frac{\text { Absorbance of Sample }- \text { Absorbance of Negative Control }}{\text { Absorbance of Positive Control }} \times 100 \%
$$

223

224 In vitro Transcription/Translation Assay. E. coli JM101 cells were made competent by 225 the rubidium chloride method. These cells were transformed with $4 \mathrm{ng}$ of Luciferase T7 226 Control DNA plasmid (Promega, Madison, WI) and spread on Luria-Bertani (LB) agar 227 plates containing $100 \mu \mathrm{g} / \mathrm{mL}$ ampicillin. After incubation at $37^{\circ} \mathrm{C}$ for $18-24$ hours, $10 \mathrm{~mL}$ 228 of LB broth containing $100 \mu \mathrm{g} / \mathrm{mL}$ ampicillin was inoculated with a single colony from the overnight plates. Plasmids were isolated and purified with the PureYield ${ }^{\mathrm{TM}}$ Plasmid MiniPrep System (Promega, Madison, WI). Plasmid concentration was measured by using a Thermo Nanodrop Spectrophotometer (Thermo Fisher Scientific, Wilmington, $D E)$ set to measure for nucleic acids (dsDNA).

E. coli T7 S30 Extract System for Circular DNA (Promega, Madison, WI) was used for production of luciferase from Luciferase T7 Control DNA plasmids. Fresh reaction mixture was prepared by adding $\mathrm{T} 7$ extract solution, $\mathrm{S} 30$ premix, and a complete amino acid mix (made by adding equal parts of two of the amino acid solutions minus one amino acid) in a 3:4:1 ratio $(\mathrm{v} / \mathrm{v} / \mathrm{v})$. Reactions were set up in test tubes containing $8 \mu \mathrm{L}$ of reaction mix, and $1 \mu \mathrm{L}$ of experimental solution $(500 \mu \mathrm{g} / \mathrm{mL}$ 
$239 \mathrm{MSI}-78,5 \mathrm{mg} / \mathrm{mL} \mathrm{MSI-78}$, or $500 \mu \mathrm{g} / \mathrm{mL}$ kanamycin) or $1 \mu \mathrm{L}$ of sterile deionized water

240 for a positive control. $1 \mu \mathrm{L}$ of isolated plasmid was then added to reactions and

241 immediately incubated for 5 minutes at $30^{\circ} \mathrm{C}$ in a water bath. After the 5 minute

242 incubation, reactions were stopped with the addition of $90 \mu \mathrm{L}$ of a bovine serum albumin

243 (BSA) solution, containing $1 \mathrm{mg} / \mathrm{mL}$ BSA and $2 \mathrm{mM}$ dithiothreitol (DTT) in $25 \mathrm{mM}$ Tris-

$244 \mathrm{HCl}$ buffer. This $10 \mathrm{x}$ dilution was sufficient to stop the reaction by diluting the

245 concentration of reaction components necessary for the production of luciferase.

246 Reaction solutions were placed on ice. Luciferase activity was measured using a

247 Synergy Mx Fluorescence Plate Reader (BioTek, Winooski, VT) set to incubate samples

248 for 10 seconds with agitation, followed by kinetic measurements with minimum interval

249 with a 2 second measurement delay. Twenty $\mu \mathrm{L}$ of each sample was mixed with $100 \mu \mathrm{L}$

250 of Luciferase Assay Reagent (Promega, Madison, WI) in a 96 well transparent

251 microplate. Each sample (sterile deionized water, $50 \mu \mathrm{g} / \mathrm{mL} \mathrm{MSI-78,500 \mu g/mL} \mathrm{MSI-78,}$

252 and $50 \mu \mathrm{g} / \mathrm{mL}$ kanamycin) was measured in duplicate. The results were normalized by

253 setting the activity in water to 1.0 .

\section{Results}

255 Differential scanning calorimetry was used to assess the thermal transitions in

256 whole E. coli JM109 cells upon addition of increasing concentrations of MSI-78 and

257 small molecule antibiotics. When performing DSC with complex samples such as whole

258 cells, it is important to assess the reproducibility of the scans and thus seven scans of

259 separately prepared untreated bacteria were performed. DSC scans of the bacterial

260 cells alone (Fig. 1, upper panel) exhibit six consistently reproducible endothermic

261 peaks, at temperatures of $29^{\circ} \mathrm{C}, 55^{\circ} \mathrm{C}, 70^{\circ} \mathrm{C}, 94^{\circ} \mathrm{C}, 102^{\circ} \mathrm{C}$, and $123^{\circ} \mathrm{C}$ (indicated by the

262 dashed lines in Fig. 1). These transitions correspond well with those found by other

263 groups (Mackey et al., 1991; Lee and Kaletunc, 2002b). Mackey et al (Mackey et al.,

264 1991) identified these transitions with the melting of membrane lipids $\left(20-40^{\circ} \mathrm{C}\right)$,

265 ribosomal components and tRNA $\left(47-85^{\circ} \mathrm{C}\right)$, and DNA and cell wall components at

266 higher temperatures $\left(95-125^{\circ} \mathrm{C}\right)$.

267 After each bacterial sample was scanned a second time (Fig. 1, lower panel), the 268 only features observed were small peaks at $29^{\circ} \mathrm{C}$ and at $117^{\circ} \mathrm{C}$, as well as even smaller 
269 peaks at 110 and $125^{\circ} \mathrm{C}$. This is consistent with the Mackey et al (Mackey et al., 1991)

270 identification of the $29^{\circ} \mathrm{C}$ peak as lipid, as well as their finding that the region from 110

271 and $125^{\circ} \mathrm{C}$ included contributions from DNA and carbohydrate transitions. Lipid

272 transitions, as well as some DNA and carbohydrate transitions, are expected to be

273 reversible, but given the crowded environment present in the whole cells, the proteins

274 are expected to denature irreversibly (Lepock, 2005).

275 Fig. 2 shows thermal scans of JM109 cells treated with increasing amounts of

276 MSI-78, ranging from $2.5 \%$ to $60 \%$, where the $\%$ expressed is the dry weight of peptide

277 compared to the dry weight of the bacteria (as in (Pius et al., 2012)). As expected for a

278 peptide believed to have a lytic mechanism, the addition of MSI-78 does cause the lipid

279 transition at $\sim 29^{\circ} \mathrm{C}$ to disappear, even with the smallest amount of MSI-78, consistent

280 with MSI-78 disruption of the lipid bilayer. However, the major change that occurs in the

281 DSC scans with MSI-78 is a decrease in the amplitude of the $55^{\circ} \mathrm{C}$ peak with increasing

282 peptide, and the concomitant appearance of a new peak at $40^{\circ} \mathrm{C}$ that increases in

283 amplitude with increasing concentrations of MSI-78. One explanation consistent with

284 this observation is an interaction between MSI-78 and the ribosomes that induces the

285 formation of a less stable ribosome structure that denatures at a lower temperature.

286 The normal protocol employed for MSI-78 treatment of the cells in this study was

287 to leave the MSI-78 in the samples during the scan - i.e. in general there was no wash

288 step to remove any excess MSI-78 that might remain free in solution rather than bound

289 to the cells. Therefor, two scans were performed in which the cells were treated with

290 MSI-78, but then the cells centrifuged and supernatant discarded to remove any excess

291 MSI-78. The result (Supplemental Fig. 1) was identical to the scans shown in Fig. 2.

292 Hence it appears that the MSI-78 is able to interact with the cells before the start of the

293 scan.

294 In order to probe the specificity of the MSI-78 effects on the DSC scans, the 295 experiments were repeated with a scrambled version of MSI-78 - i.e. a peptide with 296 identical overall amino acid composition, but the residue order scrambled so that it

297 cannot form an amphipathic helical structure. Scrambled MSI-78 is 8 times less active

298 against JM109s in MIC assays (Table 1) and also about 8 times less active against 
299 human red blood cells (Table 2). In a qualitatively similar manner to MSI-78, the

300 addition of scrambled peptide causes a decrease in the amplitude of the $55^{\circ} \mathrm{C}$ peak in

301 the DSC scans of E. coli (Fig. 3). However it takes more scrambled peptide to bring

302 about similar effects; $5 \%$ scrambled peptide causes slightly less of a decrease in peak

303 size than $2.5 \% \mathrm{MSI}-78$. And in further contrast to MSI-78, the scrambled peptide does

304 not induce a concomitant appearance in the peak at $40^{\circ} \mathrm{C}$. At $60 \%$ scrambled peptide,

305 an exotherm centered at $\sim 37^{\circ} \mathrm{C}$ is apparent. This exotherm is potentially also present

306 in the MSI-78 scans, but obscured by the appearance of the new peak at $40{ }^{\circ} \mathrm{C}$. The

307 exothermic peak at $\sim 37^{\circ} \mathrm{C}$ likely derives from metabolism of the peptide by the bacteria

308 (Lepock, 2005).

309 Since MSI-78 appears to affect the $55^{\circ} \mathrm{C}$ DSC peak associated with ribosomes,

310 further experiments were carried out with two antibiotics known to affect the 30s

311 ribosomal unit, namely streptomycin and kanamycin. Streptomycin (Fig. 4A) did not

312 cause any major changes in the DSC peaks compared to the control scans, and in

313 particular caused no change in the $55^{\circ} \mathrm{C}$ peak. With kanamycin (Fig. 4B), there was a

314 large decrease in intensity of the $55^{\circ} \mathrm{C}$ peak and a concomitant appearance of small

315 peaks at $\sim 47,52$, and $57^{\circ} \mathrm{C}$. The new small peaks may correspond to structures with

316 transition temperatures that have been modified by the kanamycin. Or alternatively, at

317 least for the 52 and $57^{\circ} \mathrm{C}$ peaks, may correspond to transitions present in the untreated

318 cells but "revealed" by the kanamycin-induced reduction in intensity for the strong $55^{\circ} \mathrm{C}$

319 peak. In any case, it is apparent that not all ribosome-affecting agents have the same

320 effect on the DSC scan of the bacteria. This is perhaps not surprising given that

321 kanamycin and streptomycin are known to have different effects on the ribosome - e.g.

322 streptomycin decreases the mobility of selected regions of the $30 \mathrm{~s}$ unit (Gromadski and

323 Rodnina, 2004), whereas kanamycin stabilizes peptidyl-tRNA binding (Semenkov et al., 324 1982).

325 In order to look for more subtle MSI-78-induced changes in the DSC

326 thermograms, three temperature ranges, from 35 to 60,68 to 75 and from 90 to $97^{\circ} \mathrm{C}$

327 were analyzed individually. For each of these temperature ranges, a linear baseline

328 was fit to the scan over the lower and upper regions of the temperature range and this

329 baseline subtracted from the data. The untreated bacteria scans were plotted first to 
330 give an idea of the reproducibility of the thermograms (Fig. 5). Upon addition of MSI-

33178 (Fig. 6), changes were seen in the scans in these regions, but, with the exception of

332 the previously discussed $55^{\circ} \mathrm{C}$ and $41^{\circ} \mathrm{C}$ peaks, the changes were of the same order

333 as the variations between control scans. Additionally, the MSI-78 induced alterations to

334 the DSC scans didn't show a consistent pattern of increase or decrease with increasing

335 peptide concentration. Thus, if there are MSI-78 induced changes in other components

336 of the cell, we cannot detect them using this method. Interestingly, the scrambled

337 peptide reduces the intensity of the peaks in the 68 to 75 and 90 to $97^{\circ} \mathrm{C}$ regions in a

338 manner that increases with increasing peptide concentration (Fig. 7). That MSI-78 has

339 greater effects than the scrambled peptide on the $55^{\circ} \mathrm{C}$ peak, but smaller effects than

340 the scrambled peptide on the rest of the thermogram, suggests that MSI-78's action is

341 more specific than the scrambled peptide. Neither streptomycin nor kanamycin

342 showed consistent changes to the 68 to 75 and 90 to $97^{\circ} \mathrm{C}$ regions (Fig. 4A and B).

343 To provide further evidence of MSI-78's effects on ribosomes, an in vitro

344 transcription/translation assay (Pedrolli and Mack, 2014) was performed. MSI-78 at 50

$345 \mathrm{ug} / \mathrm{mL}$ inhibited the synthesis of luciferase by extracted ribosomes by $\sim 50 \%$ and 500

$346 \mathrm{ug} / \mathrm{mL}$ MSI-78 knocked the activity down to the same level as $50 \mathrm{ug} / \mathrm{mL}$ kanamycin

347 (Fig. 8).

348 Discussion

349 The goal of this study was to probe potentially functional interactions of the AMP 350 MSI-78 with non-lipidic extracellular and intracellular components of intact $E$. coli, as a

351 step towards a more global understanding of how AMPs target and inhibit pathogen

352 growth. Using differential scanning calorimetry (DSC) of whole E. coli treated with MSI-

35378 we were able to show that, thermodynamically speaking, MSI-78's most striking

354 effect on the bacterial cells is on the ribosomes (Fig. 2). Increasing concentrations of

355 MSI-78 caused a decrease in the area under the ribosome peak with the concomitant

356 appearance and growth of a peak at a lower temperature, consistent with an MSI-78-

357 induced destabilization of the ribosome. This DSC identification of ribosomes as an

358 MSI-78 target was supported by the results of an in vitro transcription/translation assay

359 (Fig. 8). The data available from this study are insufficient to identify a particular 
360 mechanism by which MSI-78 disrupts ribosome function, but one possibility is that MSI-

36178 binds to a target in the ribosome complex and blocks the interaction with translation

362 substrates or induces a ribosome conformation that is less able to carry out translation.

363 While interfering with ribosome function could certainly lead to growth inhibition, it is not

364 possible to be certain from the DSC data if the disruption caused by MSI-78 is sufficient

365 to cause growth inhibition. In terms of AMP:lipid ratios, the amounts of AMP employed

366 in the DSC scans could be expected to be in the sublethal range. However, given the

367 disparate experimental conditions between MIC assays and the DSC work, such as cell

368 density (and detailed in the Introduction), AMP:lipid ratio may not provide a meaningful

369 comparison. There is indeed precedence for AMP to function via interference with

370 ribosomes, for example the AMP PR-39 (Boman et al., 1993) has been shown to inhibit

371 protein synthesis. Furthermore, magainin 2, the AMP on which the MSI-78 sequence is

372 based, has been shown to locate to the cell cytoplasm (Haukland, et al, 2001).

373 In contrast to MSI-78, a scrambled version of MSI-78 showed a weaker effect

374 (Fig. 3) on ribosomes, and unlike MSI-78, also affected other cellular components (Fig.

375 7). Together, the results with MSI-78 and its scrambled version suggest that MSI-78's

376 effects are at least somewhat dependent on its particular structural features, rather than

377 a sole function of its overall charge and hydrophobicity. This finding is consistent with

378 earlier studies that showed that disrupting the secondary structure of MSI-78's related

379 AMP, magainin 2, and analogs also disrupted their function (Chen et al., 1988;

380 Matsuzaki et al., 1997). One of the hopes for the study, that it might be possible to use

381 DSC to see interactions between MSI-78 and the carbohydrate components of the cell

382 envelope, was disappointed though, as there was too much sample-to-sample variation

383 in this region of the DSC scans to say definitively if MSI-78 had an effect on these

384 components or not. It would be interesting in future to perform DSC scans of cells

385 treated with a variety of AMPs with previously identified targets including other well-

386 studied AMPs that are thought to be lytic, as well as AMPs that target DNA or cell

387 envelope components.

388 Our earlier NMR work with MSI-78 and whole cells suggested that, in addition to

389 its well characterized lipid interactions, MSI-78 interacts with non-lipidic cell envelope

390 components and intracellular targets (Pius et al., 2012). The current study with DSC 
391 verifies that MSI-78 does indeed have an intracellular target and that this target is the

392 ribosomes. MSI-78's ability to permeabilize model and E. coli membranes has

393 previously been well documented (Hallock et al., 2003; Ramamoorthy et al., 2006;

394 Gottler and Ramamoorthy, 2009b; Lee et al., 2013). Putting all the results together, it

395 appears that MSI-78 acts via multiple mechanisms - i.e. by inhibiting ribosomal activity

396 as well as disrupting the cell membrane. Multiple researchers have suggested that at

397 least some AMPs kill target pathogens via a multi-hit mechanism (e.g. (Friedrich et al.,

398 2000; Hancock and Sahl, 2006; Jenssen et al., 2006; Marcos and Gandia, 2009;

399 Wimley, 2010; Nguyen et al., 2011)) and the DSC work is certainly consistent with a

400 multiple-hit mechanism for MSI-78. Our study only examined one AMP, and so

401 extending the results to other AMPs would be speculative. However, what it not

402 speculative is the observation that once an AMP has been found to lyse model or

403 pathogenic membranes, it is rare for that AMP to be subjected to further analysis to

404 identify potential non-lipidic mechanisms of action. One potential consequence of this

405 narrow focus with respect to an AMP's mechanism is the difficulty encountered in

406 rational design of AMPs for clinical use via optimization of AMP-lipid interactions. The

407 poor correlation between model membrane lytic activity and effectiveness in MIC

408 assays observed for some AMPs (e.g. (Friedrich et al., 2000; He et al., 2014)) may well

409 be due to the presence of non-lipid targets of an AMP that are not reflected in the model

410 membranes used for AMP optimization. Successful optimization of an AMP for clinical

411 use may well require optimization of AMP interactions with both lipid and non-lipid

412 targets of that AMP.

413 
414 Acknowledgments - The authors would like to express their gratitude to Matthias

415 Mack, for his advice on the transcription assay, Rob Brown for help with the hemolytic 416 assays, and Kapil Tahlan for fruitful discussions.

417 
444

445

446

447

448

449

450

451

452

453

\section{References}

Abuladze, MK, Sokhadze, VM, Namchevadze, EN, Kiziria, E, Tabatadze, LV, Lejava, LV, Gogichaishvili, S and Bakradze, NB, Thermal analysis of whole bacterial cells exposed to potassium permanganate using differential scanning calorimetry: a biphasic dose-dependent response to stress., ScientificWorldJournal 9 (2009), 109-117.

Alpas, H, Lee, J, Bozoglu, F and Kaletunc, G, Evaluation of high hydrostatic pressure sensitivity of Staphylococcus aureus and Escherichia coli 0157:H7 by differential scanning calorimetry., Int J Food Microbiol 87 (2003), 229-237.

Anderson, WA, Hedges, ND, Jones, MV and Cole, MB, Thermal inactivation of Listeria monocytogenes studied by differential scanning calorimetry., J Gen Microbiol 137 (1991), 1419-1424.

Andreu, D and Rivas, L, Animal antimicrobial peptides: an overview., Biopolymers 47 (1998), 415-433.

Andrushchenko, VV, Vogel, HJ and Prenner, EJ, Interactions of tryptophan-rich cathelicidin antimicrobial peptides with model membranes studied by differential scanning calorimetry., Biochim Biophys Acta 1768 (2007), 2447-2458.

Bagheri, A, Taheri-Araghi, S and Ha, BY, How Cell Concentrations Are Implicated in Cell Selectivity of Antimicrobial Peptides., Langmuir 31 (2015), 8052-8062.

Bayles, DO, Tunick, MH, Foglia, TA and Miller, AJ, Cold shock and its effect on ribosomes and thermal tolerance in Listeria monocytogenes., Appl Environ Microbiol 66 (2000), 4351-4355.

Bechinger, B and Salnikov, ES, The membrane interactions of antimicrobial peptides revealed by solid-state NMR spectroscopy., Chem Phys Lipids 165 (2012), 282301.

Belliveau, BH, Beaman, TC, Pankratz, HS and Gerhardt, P, Heat killing of bacterial spores analyzed by differential scanning calorimetry., J Bacteriol 174 (1992), 44634474.

Boman, HG, Agerberth, B and Boman, A, Mechanisms of action on Escherichia coli of cecropin P1 and PR-39, two antibacterial peptides from pig intestine., Infect Immun 61 (1993), 2978-2984.

Boucher, HW, Talbot, GH, Bradley, JS, Edwards, JE, Gilbert, D, Rice, LB, Scheld, M, Spellberg, B and Bartlett, J, Bad bugs, no drugs: no ESKAPE! An update from the Infectious Diseases Society of America., Clin Infect Dis 48 (2009), 1-12.

Brogden, KA, Antimicrobial peptides: pore formers or metabolic inhibitors in bacteria?, 
454

455

456

457

458

459

460

461

462

463

464

465

466

467

468

469

470

471

472

473

474

475

476

477

478

479

480

481

482

483

484

485

486

487

488

Nat Rev Microbiol 3 (2005), 238-250.

Brotz, H, Bierbaum, G, Leopold, K, Reynolds, PE and Sahl, HG, The lantibiotic mersacidin inhibits peptidoglycan synthesis by targeting lipid II., Antimicrob Agents Chemother 42 (1998), 154-160.

Chen, $\mathrm{HC}$, Brown, JH, Morell, JL and Huang, CM, Synthetic magainin analogues with improved antimicrobial activity., FEBS Lett 236 (1988), 462-466.

K, E and R, B (2002) (Ausubel, FM, Brent, R., Kingston, R. E., Moore, D. D., Seidman, J. G., Smith, J. A., and Struhl, K, Ed.),

Epand, RF, Umezawa, N, Porter, EA, Gellman, SH and Epand, RM, Interactions of the antimicrobial beta-peptide beta- 17 with phospholipid vesicles differ from membrane interactions of magainins., Eur J Biochem 270 (2003), 1240-1248.

Friedrich, CL, Moyles, D, Beveridge, TJ and Hancock, RE, Antibacterial action of structurally diverse cationic peptides on gram-positive bacteria., Antimicrob Agents Chemother 44 (2000), 2086-2092.

Gee, ML, Burton, M, Grevis-James, A, Hossain, MA, McArthur, S, Palombo, EA, Wade, $\mathrm{JD}$ and Clayton, $\mathrm{AH}$, Imaging the action of antimicrobial peptides on living bacterial cells., Sci Rep 3 (2013), 1557.

Gottler, LM and Ramamoorthy, A, Structure, membrane orientation, mechanism, and function of pexiganan--a highly potent antimicrobial peptide designed from magainin., Biochim Biophys Acta 1788 (2009), 1680-1686.

Gromadski, KB and Rodnina, MV, Streptomycin interferes with conformational coupling between codon recognition and GTPase activation on the ribosome., Nat Struct Mol Biol 11 (2004), 316-322.

Hall, K, Lee, TH, Mechler, Al, Swann, MJ and Aguilar, MI, Real-time measurement of membrane conformational states induced by antimicrobial peptides: balance between recovery and lysis., Sci Rep 4 (2014), 5479.

Hallock, KJ, Lee, DK and Ramamoorthy, A, MSI-78, an analogue of the magainin antimicrobial peptides, disrupts lipid bilayer structure via positive curvature strain, Biophysical Journal 84 (2003), 3052-3060.

Hancock, RE and Sahl, HG, Antimicrobial and host-defense peptides as new antiinfective therapeutic strategies., Nat Biotechnol 24 (2006), 1551-1557.

Haukland, HH, Ulvatne, H, Sandvik, K and Vorland, LH, The antimicrobial peptides lactoferricin $\mathrm{B}$ and magainin 2 cross over the bacterial cytoplasmic membrane and reside in the cytoplasm., FEBS Lett 508 (2001), 389-393. 
$489 \mathrm{He}, \mathrm{J}$, Krauson, AJ and Wimley, WC, Toward the de novo design of antimicrobial

490

491

492

493

494

495

496

497

498

499

500

501

502

503

504

505

506

507

508

509

510

511

512

513

514

515

516

517

518

519

520

521

522

523

524

peptides: Lack of correlation between peptide permeabilization of lipid vesicles and antimicrobial, cytolytic, or cytotoxic activity in living cells., Biopolymers 102 (2014), $1-6$.

Jana, J, Kar, RK, Ghosh, A, Biswas, A, Ghosh, S, Bhunia, A and Chatterjee, S, Human cathelicidin peptide LL37 binds telomeric G-quadruplex., Mol Biosyst (2013),

Jenssen, $\mathrm{H}$, Hamill, $\mathrm{P}$ and Hancock, RE, Peptide antimicrobial agents., Clin Microbiol Rev 19 (2006), 491-511.

Kaletunc, G, Lee, J, Alpas, H and Bozoglu, F, Evaluation of structural changes induced by high hydrostatic pressure in Leuconostoc mesenteroides., Appl Environ Microbiol 70 (2004), 1116-1122.

Kragol, G, Lovas, S, Varadi, G, Condie, BA, Hoffmann, R and Otvos, LJ, The antibacterial peptide pyrrhocoricin inhibits the ATPase actions of DnaK and prevents chaperone-assisted protein folding., Biochemistry 40 (2001), 3016-3026.

Lee, DK, Bhunia, A, Kotler, SA and Ramamoorthy, A, Detergent-type membrane fragmentation by MSI-78, MSI-367, MSI-594, and MSI-843 antimicrobial peptides and inhibition by cholesterol: a solid-state nuclear magnetic resonance study., Biochemistry 54 (2015), 1897-1907.

Lee, DK, Brender, JR, Sciacca, MF, Krishnamoorthy, J, Yu, C and Ramamoorthy, A, Lipid Composition-Dependent Membrane Fragmentation and Pore-Forming Mechanisms of Membrane Disruption by Pexiganan (MSI-78)., Biochemistry (2013),

Lee, $\mathrm{J}$ and Kaletunc, $\mathrm{G}$, Calorimetric determination of inactivation parameters of microorganisms., J Appl Microbiol 93 (2002a), 178-189.

Lee, $\mathrm{J}$ and Kaletunc, G, Evaluation of the heat inactivation of Escherichia coli and Lactobacillus plantarum by differential scanning calorimetry., Appl Environ Microbiol 68 (2002b), 5379-5386.

Lee, $\mathrm{J}$ and Kaletunç, $\mathrm{G}$, Inactivation of $<\mathrm{i}>$ Salmonella Enteritidis strains by combination of high hydrostatic pressure and nisin, International journal of food microbiology 140 (2010), 49-56.

Lepock, JR, Measurement of protein stability and protein denaturation in cells using differential scanning calorimetry, Methods 35 (2005), 117-125.

Lepock, JR, Frey, HE, Heynen, MP, Nishio, J, Waters, B, Ritchie, KP and Kruuv, J, Increased thermostability of thermotolerant CHL V79 cells as determined by differential scanning calorimetry., J Cell Physiol 142 (1990a), 628-634.

Lepock, JR, Frey, HE and Inniss, WE, Thermal analysis of bacteria by differential 
525

526

527

528

529

530

531

532

533

534

535

536

537

538

539

540

541

542

543

544

545

546

547

548

549

550

551

552

553

554

555

556

557

558

559

560

scanning calorimetry: relationship of protein denaturation in situ to maximum growth temperature., Biochim Biophys Acta 1055 (1990b), 19-26.

Mackey, BM, Miles, CA, Parsons, SE and Seymour, DA, Thermal denaturation of whole cells and cell components of Escherichia coli examined by differential scanning calorimetry., J Gen Microbiol 137 (1991), 2361-2374.

Mackey, BM, Miles, CA, Seymour, DA and Parsons, SE, Thermal denaturation and loss of viability in Escherichia coli and Bacillus stearothermophilus, Letters in applied microbiology 16 (1993), 56-58.

Mackey, BM, Parsons, SE, Miles, CA and Owen, RJ, The relationship between the base composition of bacterial DNA and its intracellular melting temperature as determined by differential scanning calorimetry., J Gen Microbiol 134 (1988), 11851195.

Maisetta, G, Vitali, A, Scorciapino, MA, Rinaldi, AC, Petruzzelli, R, Brancatisano, FL, Esin, S, Stringaro, A, Colone, M, Luzi, C, Bozzi, A, Campa, M and Batoni, G, pHdependent disruption of Escherichia coli ATCC 25922 and model membranes by the human antimicrobial peptides hepcidin 20 and 25., FEBS J 280 (2013), 28422854.

Maloy, WL and Kari, UP, Structure-activity studies on magainins and other host defense peptides., Biopolymers 37 (1995), 105-122.

Marcos, JF and Gandia, M, Antimicrobial peptides: to membranes and beyond., Expert Opin Drug Discov 4 (2009), 659-671.

Matsuzaki, K, Control of cell selectivity of antimicrobial peptides., Biochim Biophys Acta 1788 (2009), 1687-1692.

Matsuzaki, K, Sugishita, K, Harada, M, Fujii, N and Miyajima, K, Interactions of an antimicrobial peptide, magainin 2, with outer and inner membranes of Gramnegative bacteria., Biochim Biophys Acta 1327 (1997), 119-130.

Melo, MN, Ferre, R and Castanho, MA, Antimicrobial peptides: linking partition, activity and high membrane-bound concentrations., Nat Rev Microbiol 7 (2009), 245-250.

Milek, I, Crnigoj, M, Ulrih, NP and Kaletunc, G, In vivo characterization of thermal stabilities of Aeropyrum pernix cellular components by differential scanning calorimetry., Can J Microbiol 53 (2007), 1038-1045.

Miles, CA, Mackey, BM and Parsons, SE, Differential scanning calorimetry of bacteria., J Gen Microbiol 132 (1986), 939-952.

Mohácsi-Farkas, C, Farkas, J, Meszaros, L, Reichart, O and Andrassy, E, Thermal denaturation of bacterial cells examined by differential scanning calorimetry, Journal of thermal analysis and calorimetry 57 (1999), 409-414. 
561 Nguyen, HT, Corry, JE and Miles, CA, Heat resistance and mechanism of heat inactivation in thermophilic campylobacters., Appl Environ Microbiol 72 (2006), 908-913.

Nguyen, LT, Haney, EF and Vogel, HJ, The expanding scope of antimicrobial peptide structures and their modes of action., Trends Biotechnol 29 (2011), 464-472.

Obuchi, K, Iwahashi, H, Lepock, JR and Komatsu, Y, Calorimetric characterization of critical targets for killing and acquired thermotolerance in yeast., Yeast 16 (2000), 111-119.

Park, CB, Kim, HS and Kim, SC, Mechanism of action of the antimicrobial peptide buforin II: buforin II kills microorganisms by penetrating the cell membrane and inhibiting cellular functions., Biochem Biophys Res Commun 244 (1998), 253-257.

Pasupuleti, M, Schmidtchen, A and Malmsten, M, Antimicrobial peptides: key components of the innate immune system., Crit Rev Biotechnol 32 (2012), 143171.

Patrzykat, A, Friedrich, CL, Zhang, L, Mendoza, V and Hancock, RE, Sublethal concentrations of pleurocidin-derived antimicrobial peptides inhibit macromolecular synthesis in Escherichia coli., Antimicrob Agents Chemother 46 (2002), 605-614.

Pedrolli, DB and Mack, M, Bacterial flavin mononucleotide riboswitches as targets for flavin analogs., Methods Mol Biol 1103 (2014), 165-176.

Pius, J, Morrow, MR and Booth, $\mathrm{V},(2) \mathrm{H}$ solid-state nuclear magnetic resonance investigation of whole Escherichia coli interacting with antimicrobial peptide MSI78., Biochemistry 51 (2012), 118-125.

Porcelli, F, Buck-Koehntop, BA, Thennarasu, S, Ramamoorthy, A and Veglia, G, Structures of the dimeric and monomeric variants of magainin antimicrobial peptides (MSI-78 and MSI-594) in micelles and bilayers, determined by NMR spectroscopy, Biochemistry 45 (2006), 5793-5799.

Ramamoorthy, A, Beyond NMR spectra of antimicrobial peptides: dynamical images at atomic resolution and functional insights., Solid State Nucl Magn Reson 35 (2009), 201-207.

Ramamoorthy, A, Thennarasu, S, Lee, DK, Tan, A and Maloy, L, Solid-state NMR investigation of the membrane-disrupting mechanism of antimicrobial peptides MSI-78 and MSI-594 derived from magainin 2 and melittin, Biophysical Journal 91 (2006), 206-216.

Rossi, LM, Rangasamy, P, Zhang, J, Qiu, XQ and Wu, GY, Research advances in the development of peptide antibiotics, Journal of pharmaceutical sciences 97 (2008), 1060-1070. 
597 Semenkov, Y, Katunin, VI, Makarov, EM and Kirillov, SV, Quantitative study of kanamycin action on different functions of Escherichia coli ribosomes., FEBS Lett 144 (1982), 121-124.

Sevcsik, E, Pabst, G, Jilek, A and Lohner, K, How lipids influence the mode of action of

602 membrane-active peptides., Biochim Biophys Acta 1768 (2007), 2586-2595.

603

Shai, $Y$, Mechanism of the binding, insertion and destabilization of phospholipid bilayer

604 membranes by alpha-helical antimicrobial and cell non-selective membrane-lytic

605 peptides., Biochim Biophys Acta 1462 (1999), 55-70.

606

Spellberg, B, Guidos, R, Gilbert, D, Bradley, J, Boucher, HW, Scheld, WM, Bartlett, JG and Edwards, JJ, The epidemic of antibiotic-resistant infections: a call to action for

607

608

609

610

611

612

613

Yeung, AT, Gellatly, SL and Hancock, RE, Multifunctional cationic host defence the medical community from the Infectious Diseases Society of America., Clin Infect Dis 46 (2008), 155-164.

Subbalakshmi, C and Sitaram, N, Mechanism of antimicrobial action of indolicidin., FEMS Microbiol Lett 160 (1998), 91-96.

Teixeira, P, Castro, H, Mohacsi-Farkas, $\mathrm{C}$ and Kirby, R, Identification of sites of injury in Lactobacillus bulgaricus during heat stress., J Appl Microbiol 83 (1997), 219-226.

Tunick, MH, Bayles, DO and Novak, JS, DSC analysis of foodborne bacteria, Journal of thermal analysis and calorimetry 83 (2006), 23-26.

Wimley, WC, Describing the mechanism of antimicrobial peptide action with the interfacial activity model., ACS Chem Biol 5 (2010), 905-917.

Wimley, WC and Hristova, K, Antimicrobial peptides: successes, challenges and unanswered questions., J Membr Biol 239 (2011), 27-34.

Zasloff, M, Magainins, a class of antimicrobial peptides from Xenopus skin: isolation, characterization of two active forms, and partial cDNA sequence of a precursor.,

623

624 Proc Natl Acad Sci U S A 84 (1987), 5449-5453.

625

Zasloff, M, Antimicrobial peptides of multicellular organisms, Nature 415 (2002), 389395.

626

627 
628 Table 1 - Minimal inhibitory concentration (MIC) data for JM109 E. coli with MSI-78 and 629 scrambled MSI-78. The experiments were performed in triplicate - identical values for 630 each peptide were obtained each time.

631

\begin{tabular}{|l|l|}
\hline MSI-78 & $\begin{array}{l}\text { Mean MIC against } \\
\text { JM109 (ug/ml) }\end{array}$ \\
\hline MSI-78 & 2.0 \\
\hline MSI-78s & 16.5 \\
\hline
\end{tabular}

632

633

634

635 
636 Table 2: Hemolytic Activity of MSI-78 and scrambled MSI-78. The values indicated are 637 the average of absorbance measurements from 3 samples measured at $541 \mathrm{~nm}$. 638

\begin{tabular}{|l|l|l|l|}
\hline Sample & $\begin{array}{l}\text { Average } \\
\text { Absorbance }\end{array}$ & $\begin{array}{l}\text { Standard } \\
\text { Deviation }\end{array}$ & \% Hemolysis \\
\hline Negative Control & 0.033 & 0.0039 & N/A \\
Positive Control & 0.870 & 0.064 & N/A \\
$24.35 \mu \mathrm{g} / \mathrm{mL} \mathrm{MSI-78}$ & 0.093 & 0.0059 & $6.90 \%$ \\
$48.7 \mu \mathrm{g} / \mathrm{mL} \mathrm{MSI-78}$ & 0.116 & 0.010 & $9.54 \%$ \\
$24.35 \mu \mathrm{g} / \mathrm{mL}$ & 0.0517 & 0.0074 & $2.15 \%$ \\
scrambled MSI-78 & & & \\
$48.7 \mu \mathrm{g} / \mathrm{mL}$ scrambled & 0.0493 & 0.0041 & $1.87 \%$ \\
$\mathrm{MSI}-78$ & & &
\end{tabular}




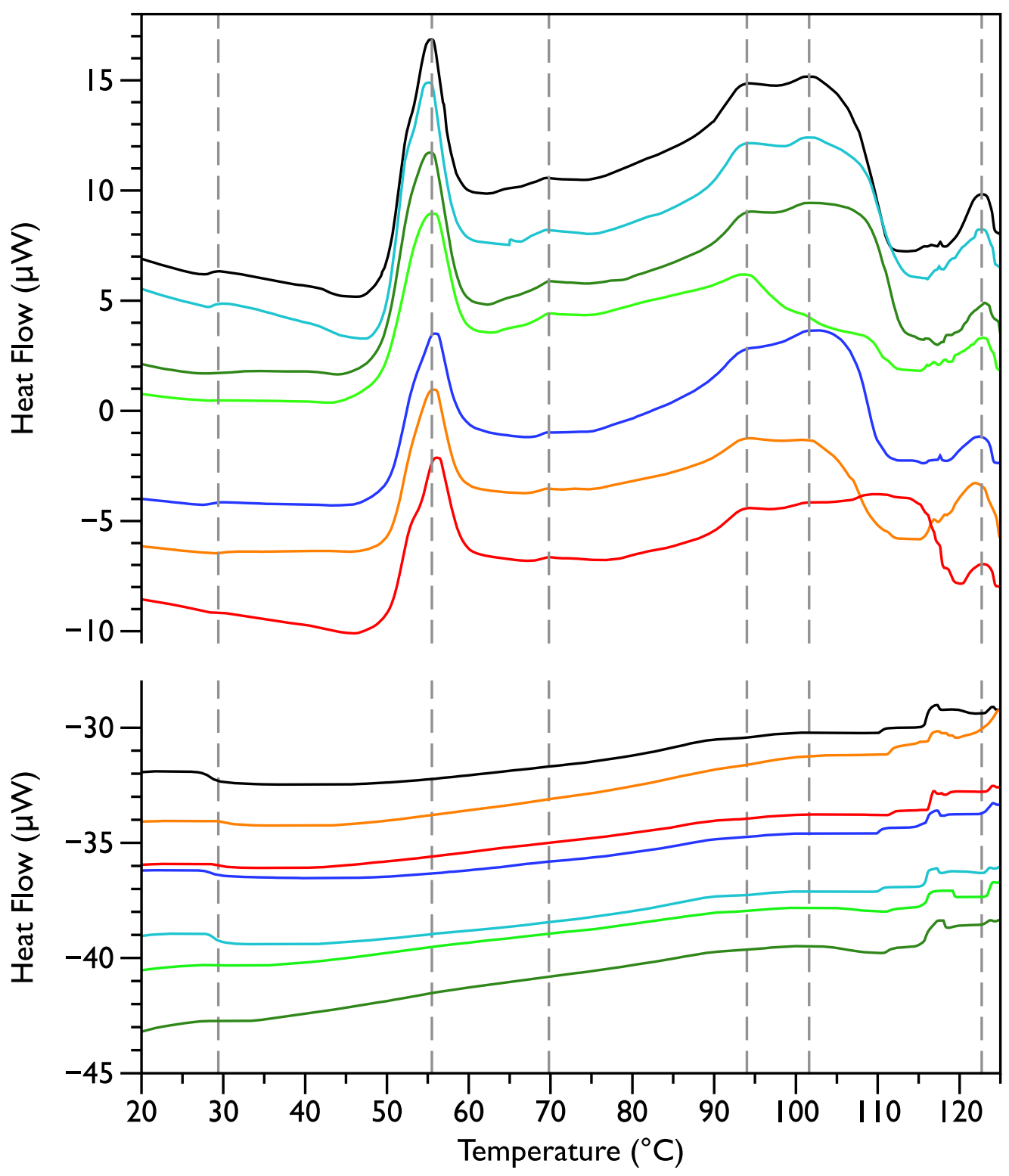

640

Temperature $\left({ }^{\circ} \mathrm{C}\right)$

641

642

643

644

645

646

647

648

649

650

651

652
Figure 1: Differential Scanning Calorimetry scans of untreated E. coli JM109 cells.

Thermograms for seven different samples, are displayed with an arbitrary vertical offset. The initial scans are shown in the upper panel and the rescans are shown below in the same colour as the first scan. A linear baseline has been subtracted from each of the initial scans but the rescans are shown unmodified. The scan shown in black is the most similar scan to the average of all the control scans and was selected to display in the rest of the figures for comparison. Grey dotted vertical lines indicate peaks that were consistently observed in all initial scans. 


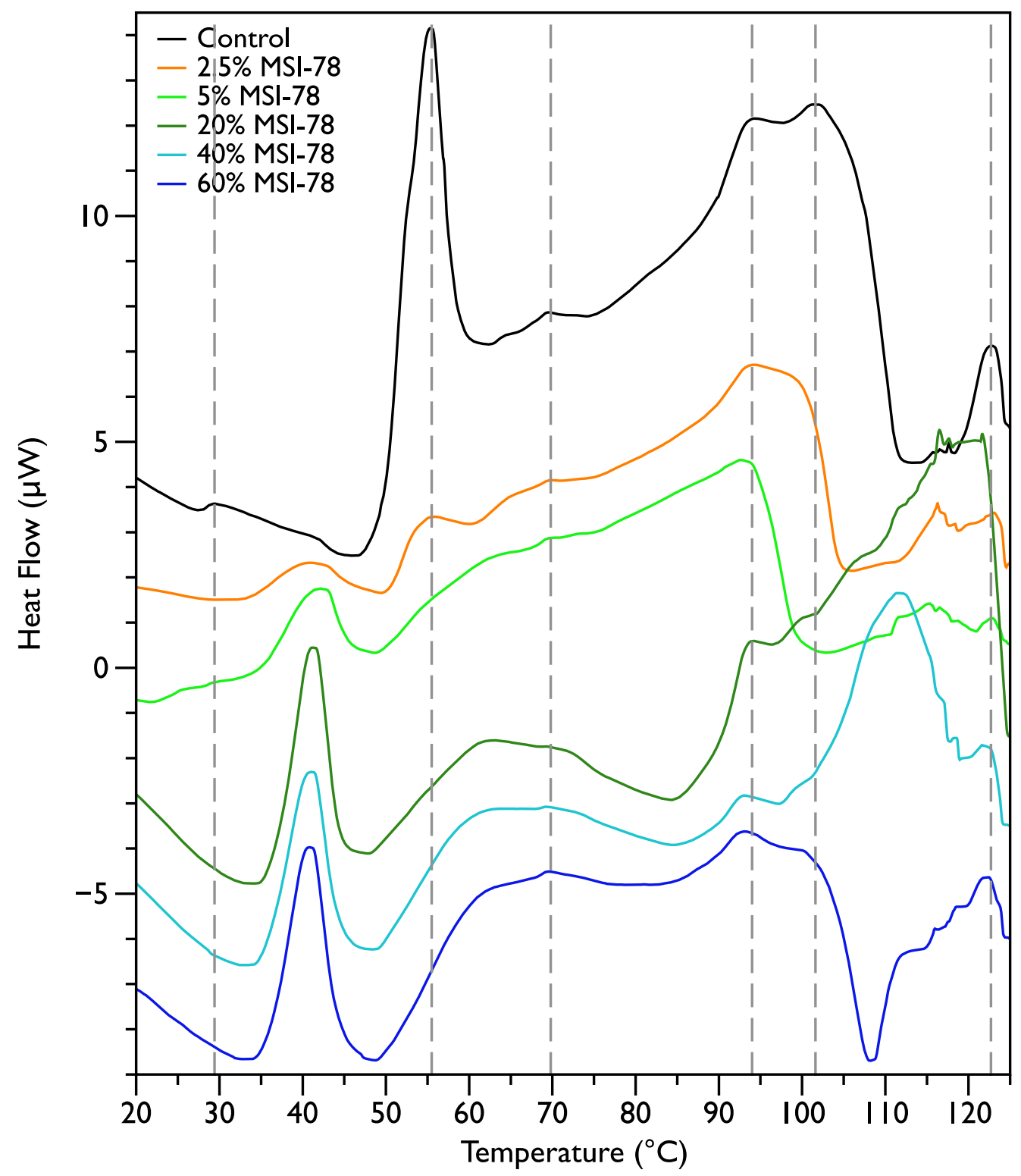

653

654

655 Figure 2: Differential Scanning Calorimetry scans of E. coli JM109 cells treated

656 with the AMP MSI-78

657

658

JM109 cells were treated with 0 to $60 \%$ weight MSI-78 per dry weight of cells. 


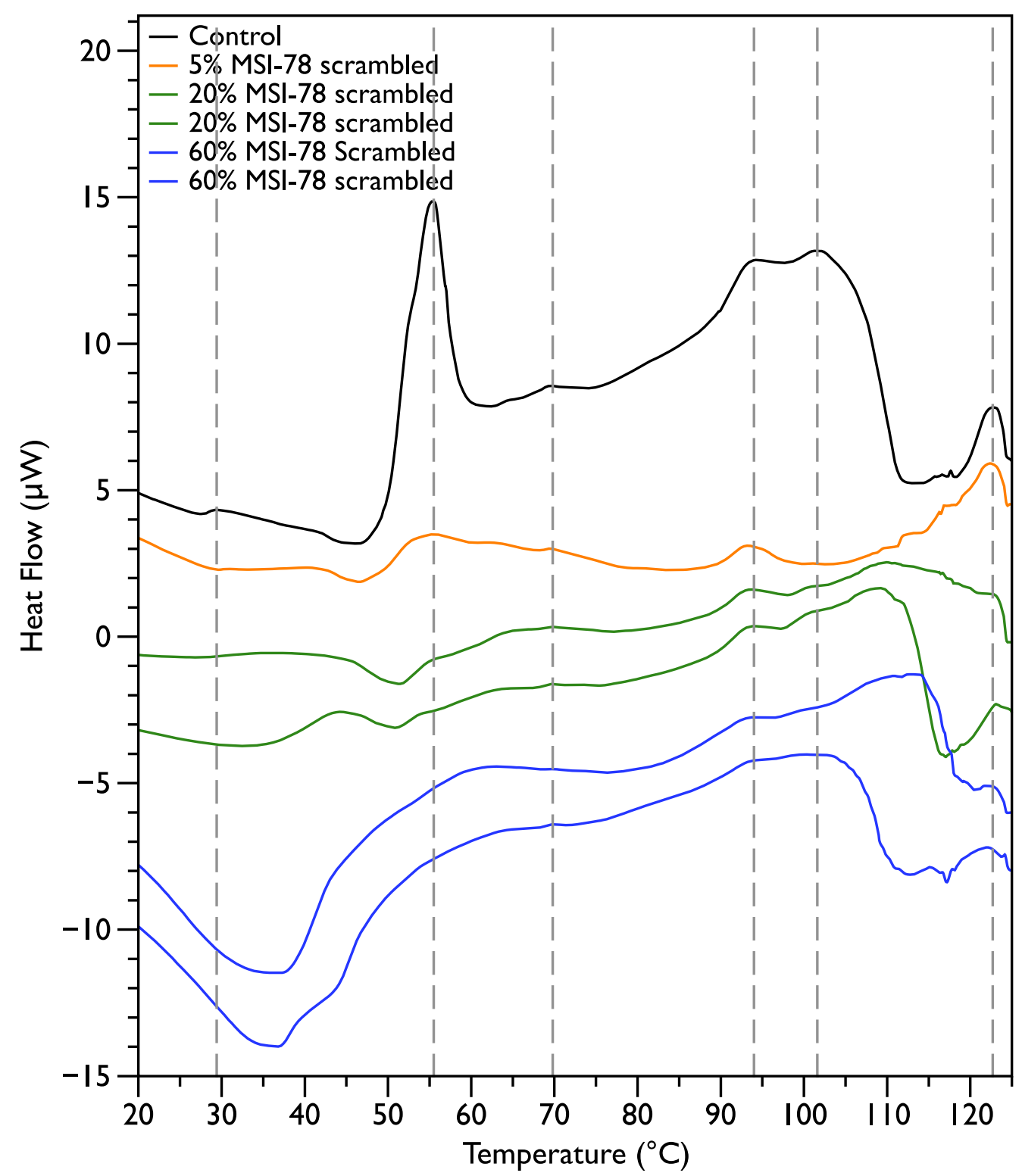

660 661 662 663 664 665 666 667 668 669 670 671 672 673
Figure 3: Differential Scanning Calorimetry scans of $E$. coli JM109 cells with addition of a scrambled variant of MSI-78

JM109 cells were treated with a scrambled variant of MSI-78, i.e. a peptide with the same amino acid content as MSI-78 but the primary sequence order scrambled so it cannot form an amphipathic alpha-helix. 
674

675

676

677

678

679

680

681

682

683 芩

684

685

686

687

688

689

690

691

692

693

694

695

696

697

698

699

700

701

702
B

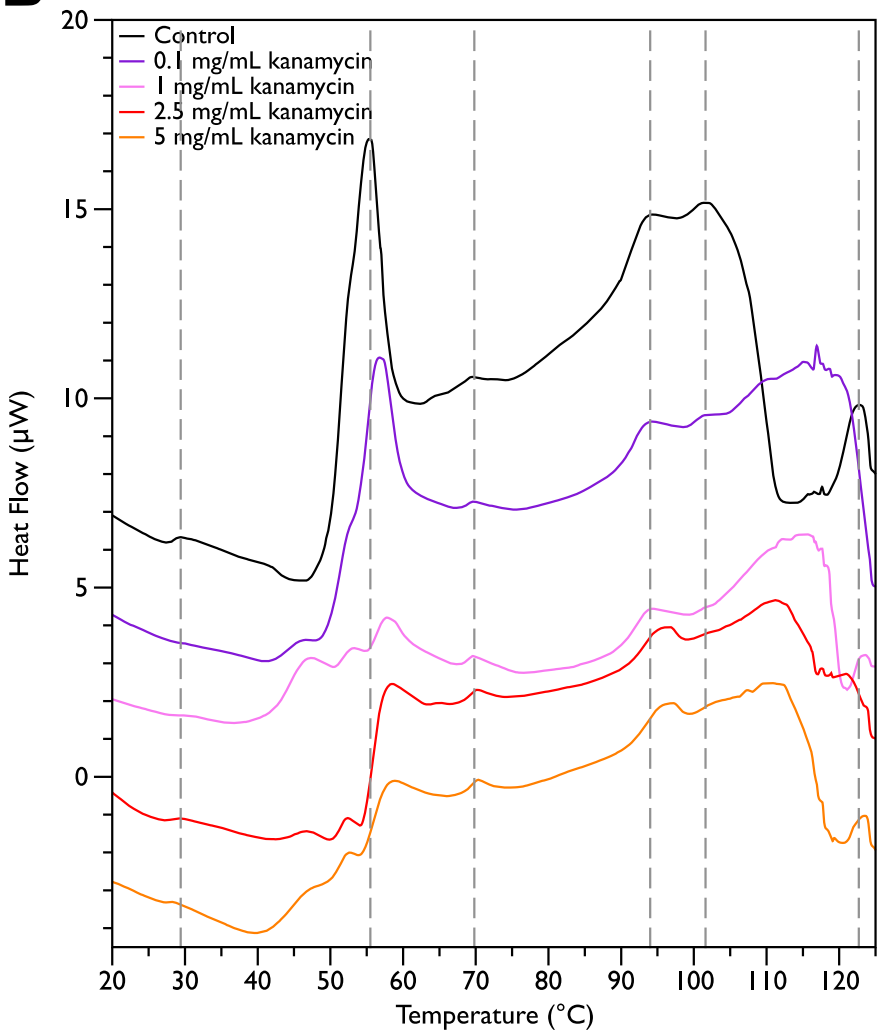

Figure 4: Differential Scanning Calorimetry Scans of E. coli JM109 cells treated with various concentrations of aminoglycoside antibiotics streptomycin and kanamycin

JM109 cells were treated with the antibiotic (A) streptomycin, and (B) kanamycin. Both are inhibitors of the bacterial $30 \mathrm{~S}$ small ribosomal subunit. 
703

704

705

706

707

708

709

710

711

712

713

714

715

716

717

718

719

720

721

722

723

724

725

726

727

728

729

730

731

732
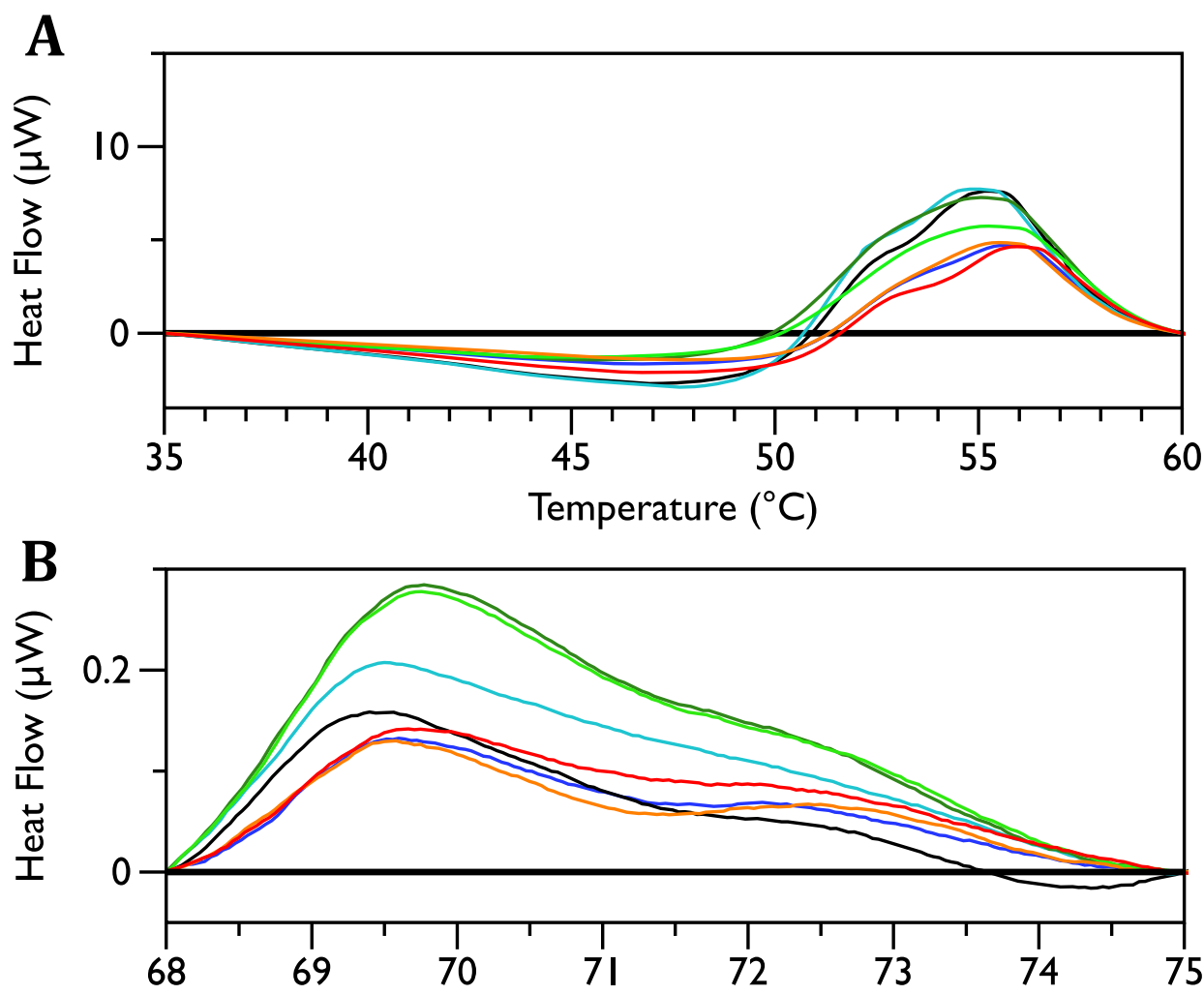

Temperature $\left({ }^{\circ} \mathrm{C}\right)$

C

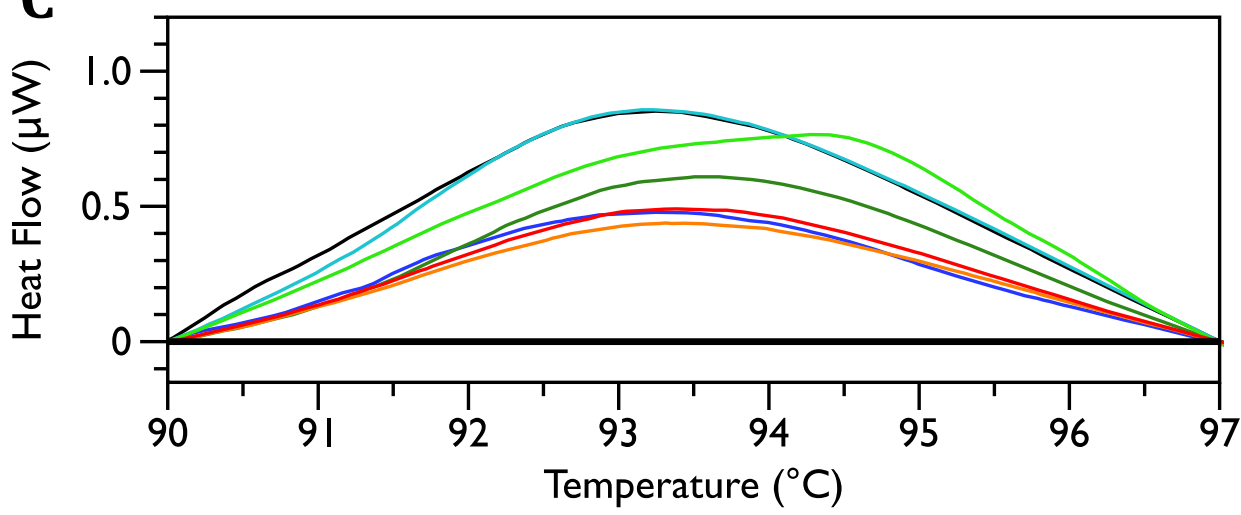

Figure 5: DSC scans of untreated E. coli JM109 cells with temperature ranges analyzed separately.

A linear baseline was fit to each scan over the lower and upper regions of each temperature range and this baseline subtracted from the data $(\mathrm{A}) 35$ to $60^{\circ} \mathrm{C},(\mathrm{B}) 68$ to $75^{\circ} \mathrm{C}$, and (C) 90 to $97^{\circ} \mathrm{C}$. 
733

734

735

736

737

738

739

740

741

742

743

744

745

746

747

748

749

750

751

752

753

754

755

756

757

758

759

760

761

762

763

764

765

A - Untreated

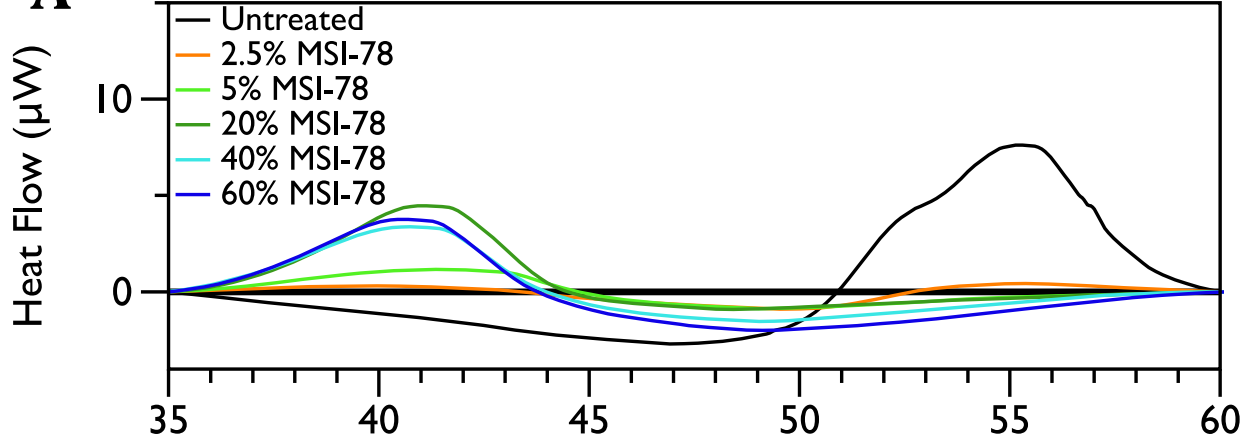

Temperature $\left({ }^{\circ} \mathrm{C}\right)$

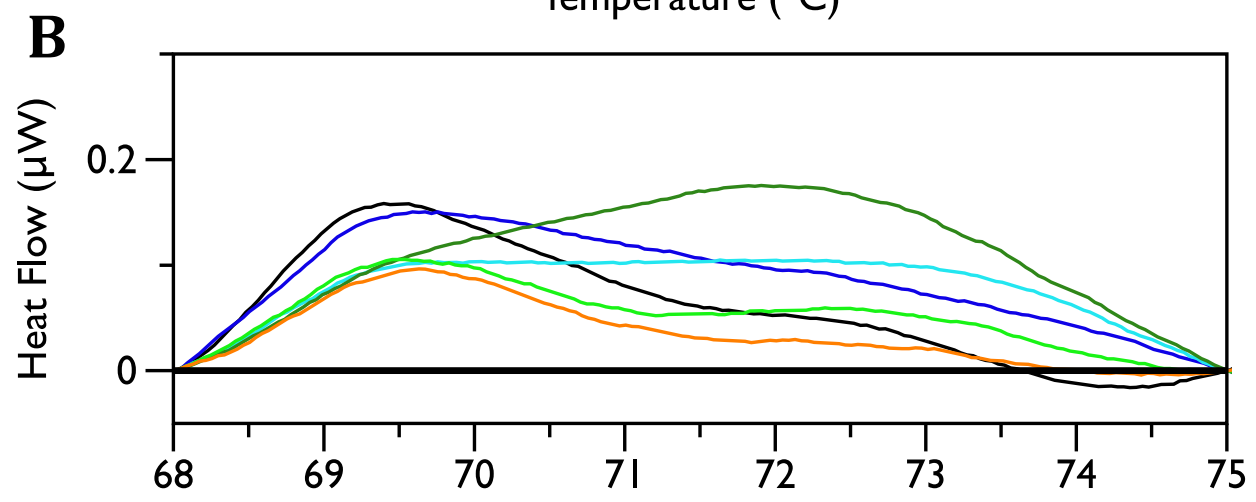

Temperature $\left({ }^{\circ} \mathrm{C}\right)$

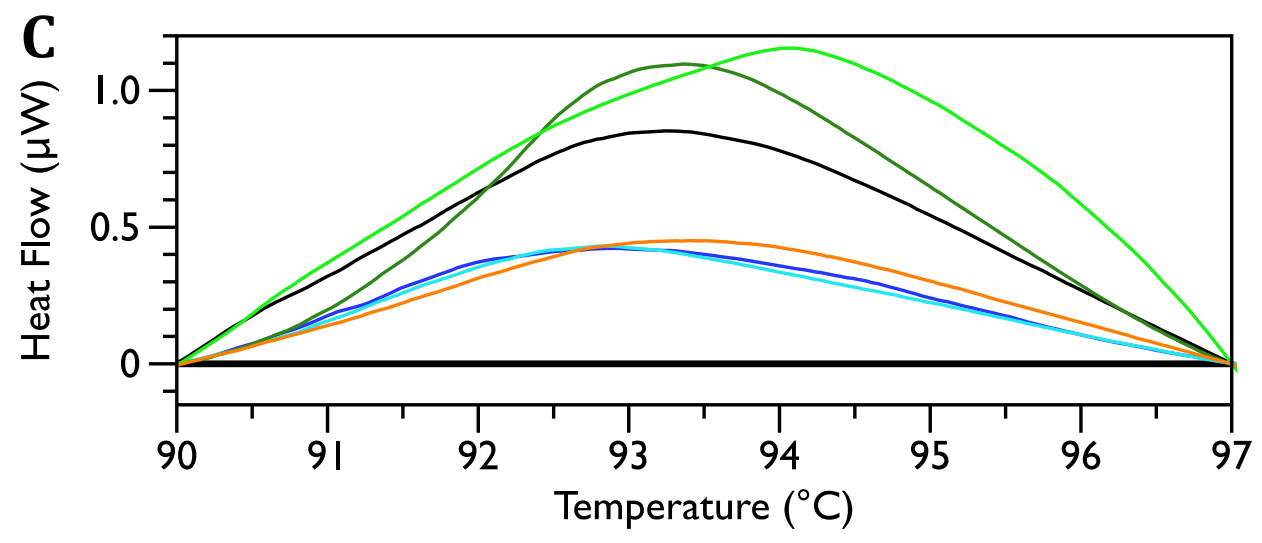

Figure 6: DSC Scans of E. coli JM109 Cells treated with MSI-78 with temperature ranges analyzed separately.

A linear baseline was fit to each scan over the lower and upper regions of each temperature range and this baseline subtracted from the data (A) 35 to $60^{\circ} \mathrm{C},(\mathrm{B}) 68$ to $75^{\circ} \mathrm{C}$, and (C) 90 to $97^{\circ} \mathrm{C}$. The colours match those from Figure 2 . 
766

767

768

769

770

771

772

773

774

775

776

777

778

779

780

781

782

783

784

785

786

787

788

789

790

791

792

793

794

795

796

797

798

799

800

801

802

803

804

805

806

807

808
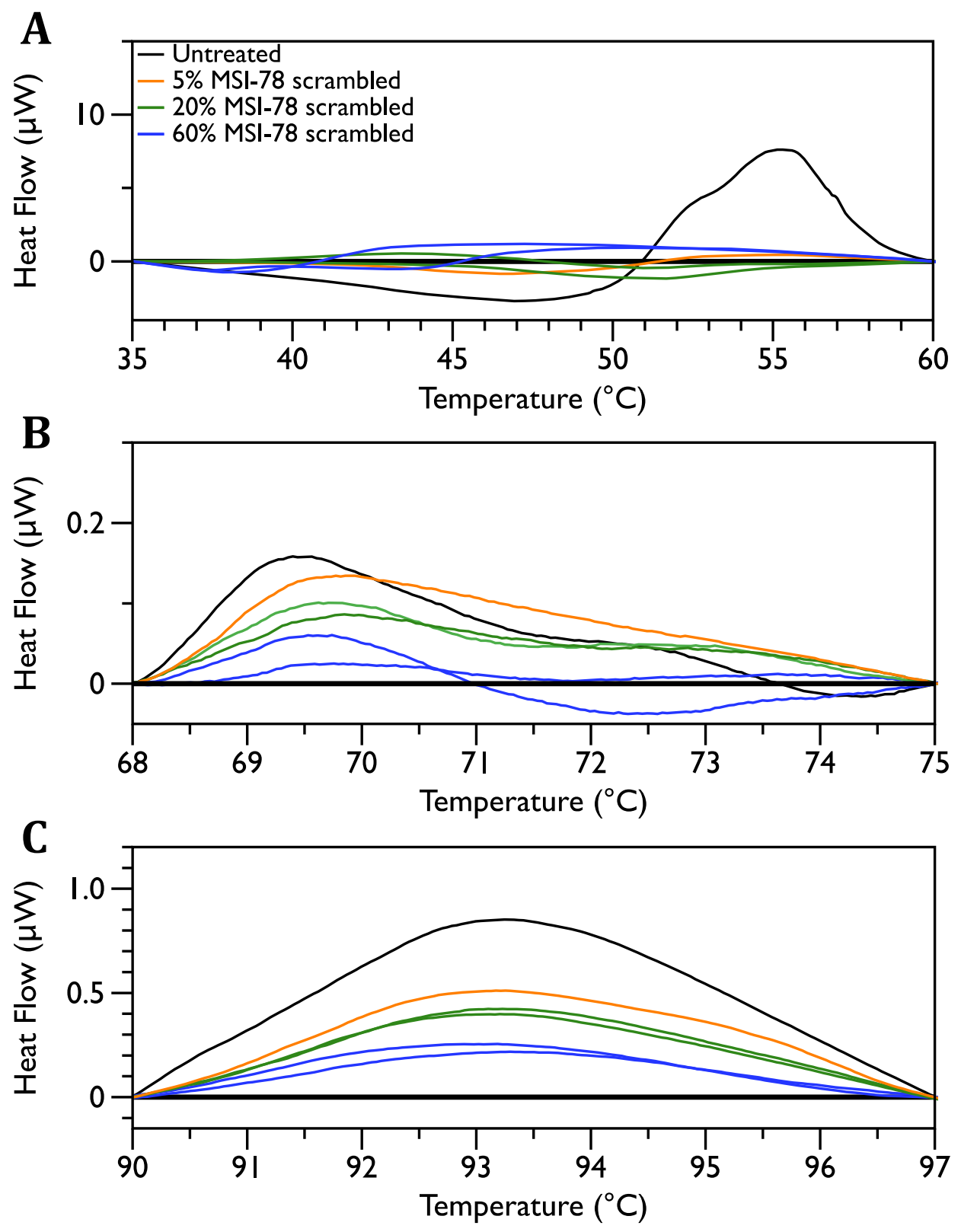

Figure 7: DSC Scans of E. coli JM109 Cells treated with scrambled MSI-78 with temperature ranges analyzed separately.

A linear baseline was fit to each scan over the lower and upper regions of each temperature range and this baseline subtracted from the data (A) 35 to $60^{\circ} \mathrm{C},(\mathrm{B}) 68$ to $75^{\circ} \mathrm{C}$, and $(\mathrm{C}) 90$ to $97^{\circ} \mathrm{C}$. The colours match those from Figure 3. 
809

810

811

812

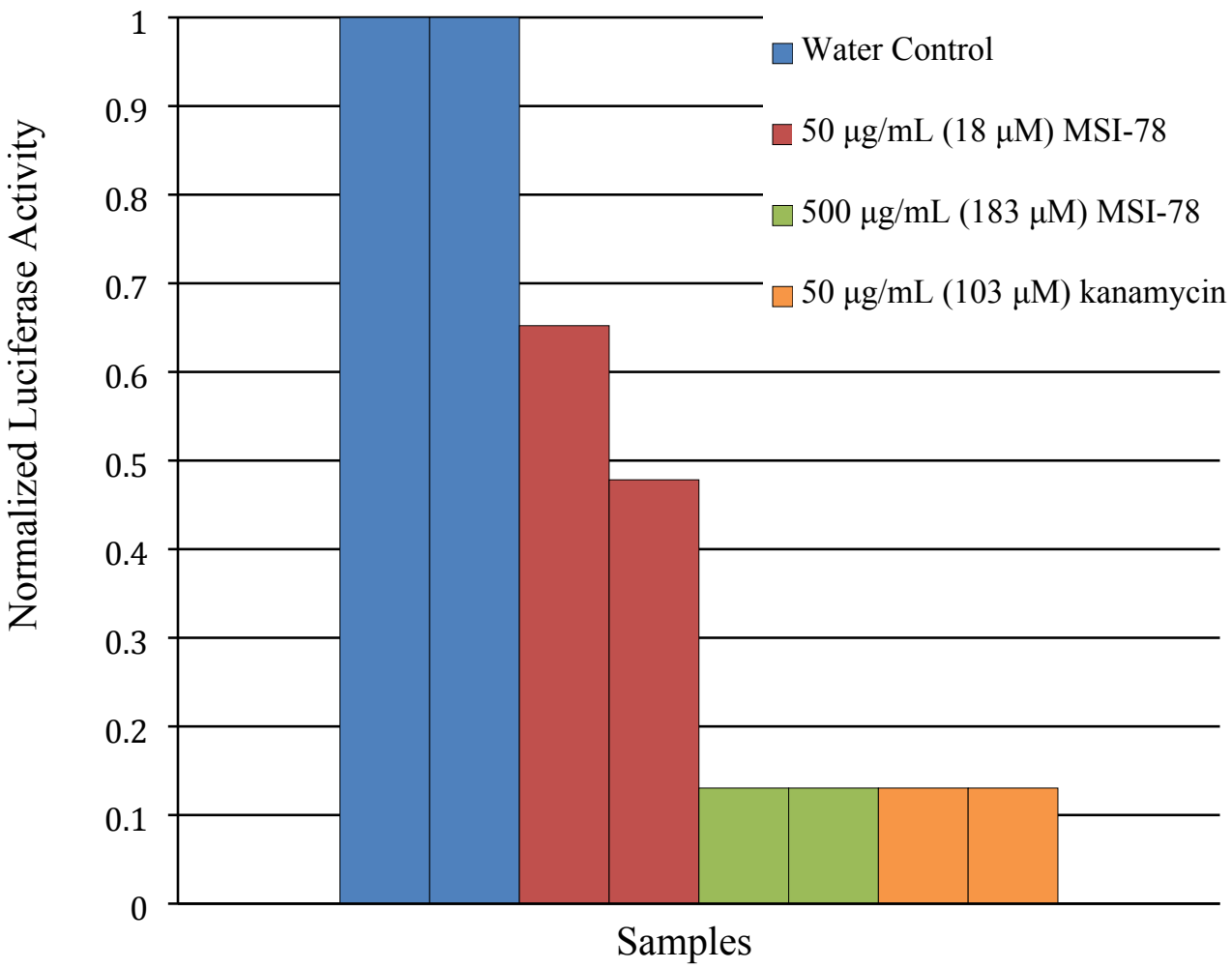

813

814

815 Figure 8: Normalized Luciferase Activity of In Vitro Transcription/Translation 816 Assay of Vector-bound Luciferase to Test for Inhibition of Protein Synthesis 817

818 


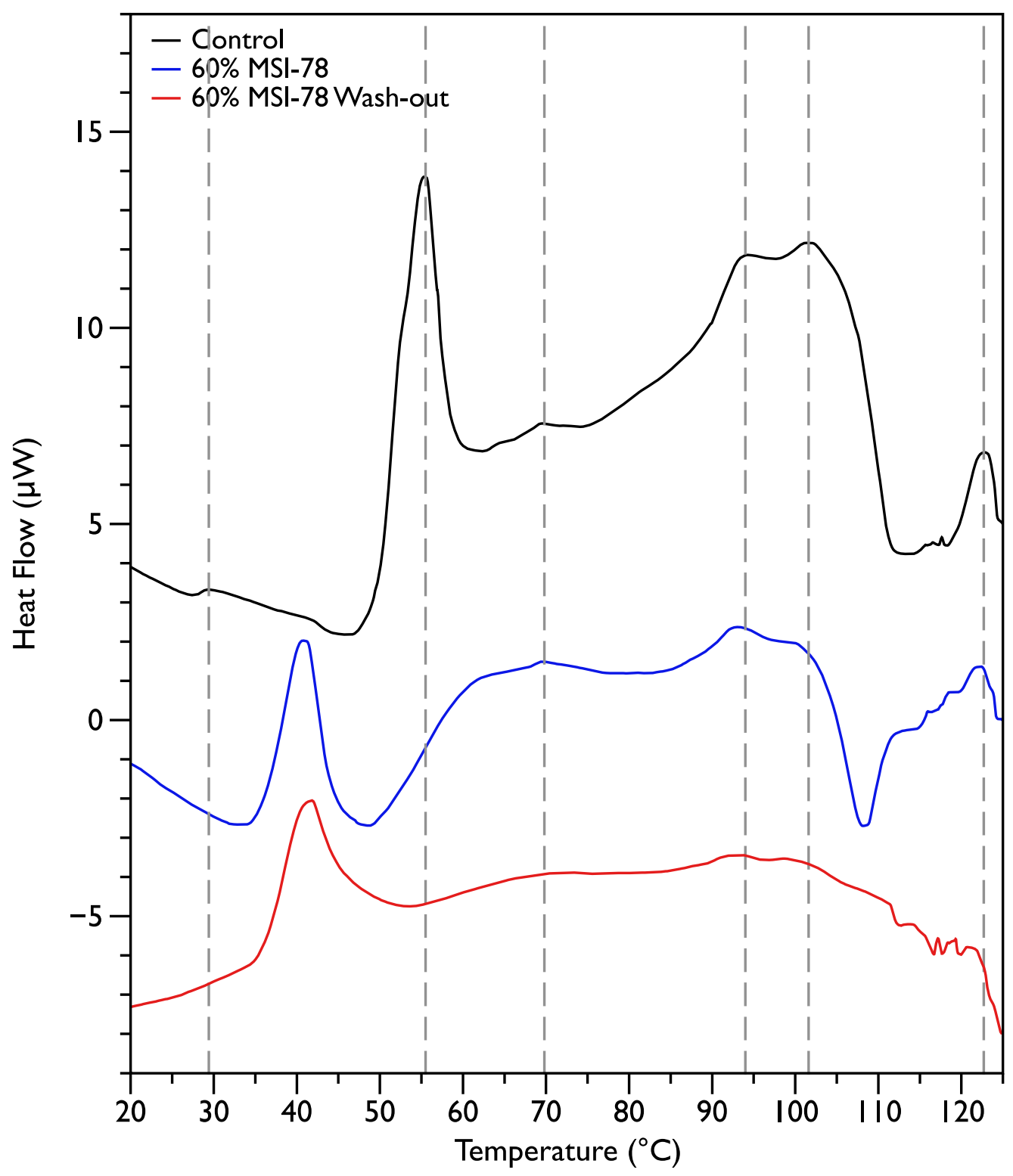

819

Temperature $\left({ }^{\circ} \mathrm{C}\right)$

820

821

822

823

824 Supplementary Figure 1: DSC scans of $E$. coli JM109 cells comparing cells treated with 825 MSI-78 with and without a step to wash out unbound MSI-78 prior to the start of the 826 DSC scan.

827 